\title{
PENGARUH PEMBERIAN BISA NAJA SPUTATRIX TERHADAP KADAR INTERLEUKIN-2 SERUM DARAH MENCIT YANG DIINDUKSI BENZO(A)PYRENE
}

\author{
Gina Anindyajati (gina_anindyajati@yahoo.com) \\ Bambang Budiono (bambang.budiono@yahoo.com) \\ Rismanto Joyosumarto (rismanto@yahoo.com) \\ Fakultas Kedokteran Universitas Gadjahmada
}

\begin{abstract}
Cancer has become a global health problem arisen from exposure to benzo(a)pyrene. Interleukin-2 is one of immune system components believed to play roles in eradicating cancer. Cobra venom has antitumor effect and also contain protease which could boost up immune system. This research was aimed at analyzing Naja sputatrix venom's effect to increase interleukin-2 level in blood sera of mice induced by benzo(a)pyrene. Four group of Balb-C mice were used. The first group (control) and second group (treatment with Naja sputatrix venom) consist of 5 mices. There are 6 mices used in group 3 and 4 , both were injected intramuscularly by benzo(a)pyrene $(0,3 \mu \mathrm{L} / 0,01 \mathrm{~mL}$ oleum oil) at day 1, 8 and 15. Three months after, observation was carried out to see changes occured in their liver and lungs. Naja sputatrix venom 0,1 $\mathrm{mL}$ (diluted in saline 1:100) was given to group 2 and 4 for 30 days. Blood was collected from all groups and centrifuge to form sera. Level of interleukin-2 in sera was measured by ELISA method. The results show that Group 2 has the highest mean level of interleukin-2 (136,837 pg/mL), and group 3 has the lowest $(8,996 \mathrm{pg} / \mathrm{mL})$. Level of interleukin-2 in group 4 is slightly higher than group $3(10,632 \mathrm{pg} / \mathrm{mL})$. Kruskal-Wallis analysis result come with Sig. 0,155; therefore shows no significance $(p>0,05)$. It is therefore concluded that Naja sputatrix venom do not increase interleukin-2 level in blood sera of mice induced by benzo(a)pyrene
\end{abstract}

Key words : benzo(a)pyrene, interleukin-2, naja sputatrix venom

Kanker menjadi masalah kesehatan global karena banyak menimbulkan kematian dan jumlah kasus baru meningkat tiap tahun. Kanker dapat disebabkan oleh beberapa hal, salah satunya adalah paparan terhadap karsinogen seperti benzo(a)pyrene $(\mathrm{B}(\mathrm{a}) \mathrm{P})$ yang menyebabkan perubahan sel ke arah keganasan (Heussen, Post, \& Alink, 1990; Soedigdo, 1975; Wagener, Van de Velde, \& Bosnan, (1999). Penelitian yang dilakukan oleh Kapitulnik, Wislocki, dan Levin, (1978) menunjukkan bahwa B(a)P yang diinjeksikan secara intraperitoneal pada bayi mencit dapat menimbulkan adenoma pada paru, hepar, dan serviks uterus.

Pengobatan terhadap kanker selama ini berkutat pada eradikasi sel kanker dengan metode radiasi dan kemoterapi. Namun beberapa penelitian menunjukkan bahwa kedua metode tersebut cenderung menurunkan kadar dan aktivitas sistem imun (Heussen et al., 1990). Padahal sistem imun tubuh manusia memiliki mekanisme tersendiri untuk memberikan perlawanan terhadap sel kanker. Mekanisme ini antara lain diperankan oleh sel T helper $\mathrm{CD} 4$ + yang mengeluarkan sitokin interleukin2 (IL-2) ke dalam darah (Roitt, 1991).

Sel T helper akan mengenali antigen sel kanker dan memproduksi sitokin berupa IL-2 yang kemudian memacu sel T sitotoksik untuk berinteraksi dengan sel kanker dan mematikan sel tersebut. 
Induksi sifat sitotoksik oleh sitokin inilah yang digunakan sebagai bentuk imunoterapi yang terakhir. IL-2 juga turut menguatkan efek pembunuhan terhadap sel kanker oleh sel NK sebagai reaksi imun yang nonspesifik (Wagener et al., 1999). Karena itulah muncul pertanyaan mengenai kemungkinan memanipulasi sistem imun sehingga mampu membunuh sel kanker dalam jumlah yang lebih banyak untuk mencapai taraf kesembuhan (Mathé, 1976).

Telah diketahui bahwa protease mampu meningkatkan kemampuan sistem imun (Feofanov et al, 2005) dan protease terdapat dalam bisa ular kobra (Ganesha, 2001). Bisa ular merupakan suatu bahan biologis alami yang mengandung beberapa komponen dan mungkin memiliki potensi nilai terapeutik (Pal, Gomes, Dasgupta, \& Gomes 2002). Bisa ular kobra dari genus Naja mengandung banyak protein spesifik yang memiliki efek sitotoksik, hemolitik serta neurotoksik. Selain itu, bisa ular kobra juga mengandung banyak enzim termasuk kobramin dan kobralisin (Anonim, 1998).

Dalam suatu penelitian dilaporkan bahwa komponen sitotoksin dari bisa ular kobra memiliki efek sitotoksik yang lebih terhadap sel-sel tumor dibanding dengan sel-sel normal secara in vitro (Shaikh, Jamali, Ansari, \& Seehar, 1986). Senyawa sitotoksis tersebut adalah lipase dan protease. Lipase memiliki kemampuan merusak membran sel kanker sehingga sel imun akan mampu mengenali sel kanker dan membunuhnya (Ganesha, 2001). Sementara itu, protease adalah enzim yang dilaporkan mempunyai kemampuan meningkatkan aktifitas imun (Feofanov, et.al. 2005).

Beberapa penelitian menunjukkan bahwa bisa ular kobra memiliki efek antitumor (Calmette, Saenz, \& Costil, 1933; Bragança, Patel, \& Bradinath, 1967), meskipun mekanismenya untuk membunuh sel kanker sampai saat ini masih belum jelas dan terus dilakukan penelitian. Untuk mengetahui hal tersebut maka penelitian ini dilakukan.

Penelitian ini dilakukan dengan memberikan bisa Naja sputatrix kepada mencit yang telah diinduksi dengan B(a)P. Pengaruh yang ditimbulkan oleh bisa Naja sputatrix terhadap sistem imun mencit dilihat melalui pengukuran kadar IL-2 dalam serum darah menggunakan teknik enzym linked immunosorbent assay (ELISA).

\section{METODOLOGI}

Rancangan penelitian yang digunakan adalah penelitian eksperimental dengan menggunakan 4 kelompok mencit Balb-C. Kelompok 1 dan 2 terdiri dari 5 ekor mencit, sementara kelompok 3 dan 4 terdiri dari 6 ekor mencit. Kelompok 1 merupakan kelompok kontrol, kelompok 2 merupakan kelompok perlakuan dengan pemberian bisa ular, kelompok 3 diberi $B(a) P$, serta kelompok 4 menerima B(a)P dan bisa ular. Pemberian B(a)P dilakukan saat usia mencit 1, 8, dan 15 hari secara intramuskularis dengan dosis $0,3 \mu \mathrm{l} / 0,01 \mathrm{~mL}$ minyak oleum. Tiga bulan setelahnya dilihat perubahan yang terjadi pada organ hepar dan paru-paru, dilanjutkan dengan pemberian bisa ular kepada kelompok 2 dan 4 selama 30 hari dengan dosis $0,1 \mathrm{~mL}$ setelah diencerkan dengan salin 1:100 menggunakan sonde. Setelah itu darah diambil dari seluruh kelompok mencit dan dibuat serum untuk kemudian dihitung kadar IL-2 nya dengan metode ELISA.

\section{HASIL}

Setelah induksi dengan B(a)P pada Kelompok mencit 3 dan 4, pada bulan ketiga diambil masing-masing satu ekor mencit secara acak dan dilihat perubahan yang terjadi pada sel di hepar serta paru-paru menggunakan mikroskop. Hasilnya menunjukkan tiga perubahan pada hepar, yaitu 
mitosis patologis, sel-sel piknotik, serta gambaran infiltrat periportal. Sementara itu pada paru-paru ditemukan gambaran berupa udem pulmonal, penebalan pada septum intraalveolar, dan metaplasia pada sel bronkus.

Serum yang dikumpulkan dipakai untuk pembacaan kadar IL-2 dengan metode ELISA. Kadar IL-2 dari masing-masing kelompok mencit disajikan dalam Tabel 1.

Tabel 1. Rerata Kadar IL-2 Mencit

\begin{tabular}{cll}
\hline Kelompok & & \multicolumn{1}{c}{ Perlakuan } \\
\hline 1 & Kontrol & $13,796 \pm 3,11$ \\
2 & Bisa Naja sputatrix & $136,837 \pm 246,63$ \\
3 & B(a)P & $8,996 \pm 1,513$ \\
4 & B(a)P + Bisa Naja sputatrix & $10,632 \pm 5,635$ \\
\hline
\end{tabular}

Perbandingan rerata kadar IL-2 mencit yang diperoleh digambarkan dalam Gambar 1.

Perbandingan Rerata Kadar IL-2

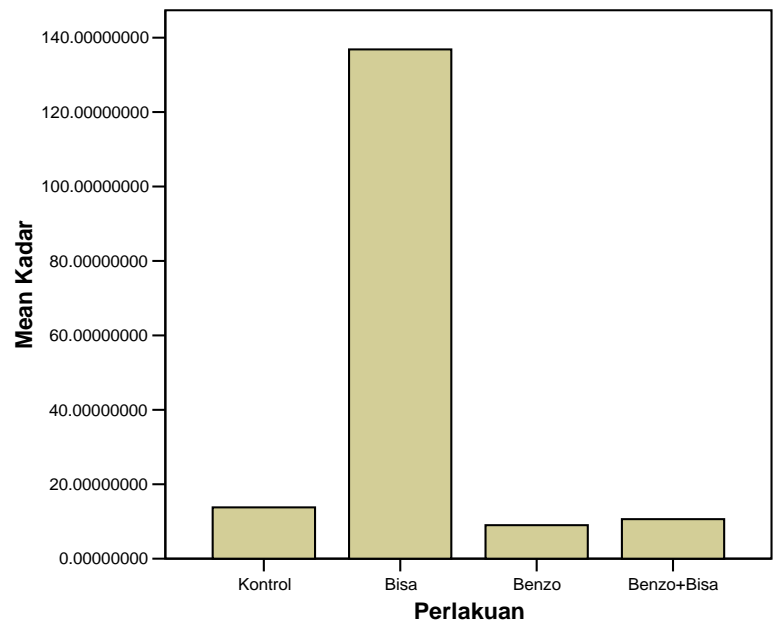

Gambar 1. Perbandingan rerata kadar IL-2 mencit

Rerata kadar IL-2 tertinggi didapatkan pada Kelompok 2, yakni kelompok yang mendapatkan perlakuan dengan bisa Naja sputatrix saja (136,837 pg/mL). Kelompok mencit 3 dengan pemberian $\mathrm{B}(\mathrm{a}) \mathrm{P}$ saja memiliki rerata kadar IL-2 yang terendah yaitu $8,996 \mathrm{pg} / \mathrm{mL}$. Sementara Kelompok mencit 4 dengan pemberian B(a)P dan bisa Naja sputatrix, memiliki rerata yang sedikit lebih tinggi $(10,632$ $\mathrm{pg} / \mathrm{mL}$ ) dibandingkan Kelompok mencit 3. Penghitungan dengan One Way ANOVA tidak dapat dilakukan karena tidak memenuhi syarat sehingga diganti dengan uji non parametrik Kruskal-Wallis yang menghasilkan Sig. 0,155. Secara statistik ke empat kelompok ini tidak memiliki perbedaan yang bermakna $(p>0,05)$. 


\section{PEMBAHASAN}

Kelompok mencit yang hanya diberi B(a)P memiliki kadar IL-2 yang paling kecil. Hal ini sejalan dengan penelitian yang menemukan bahwa pertumbuhan tumor atau proses karsinogenesis (yang dalam penelitian ini diinduksi oleh $\mathrm{B}(\mathrm{a}) \mathrm{P}$ ) akan menurunkan sistem imun terutama sistem imun seluler non spesifik yang diperankan oleh makrofag (Bal et. al., 1984). Diasumsikan bahwa makrofag tidak berfungsi optimal sehingga senyawa reaktif yang dihasilkan dari aktivitas fagosit, Reactive Oxygen Intermediates (ROI), tidak cukup terbentuk. Padahal, ROI memiliki kemampuan luar biasa untuk memecah molekul antigen menjadi partikel yang lebih kecil dan mempresentasikannya ke sistem imun seluler spesifik (Baratawidjaya, 1988; Roitt, Brostoff, \& Male , 1996). Salah satu komponen sistem imun seluler spesifik adalah limfosit T. Jika jumlah limfosit T yang teraktivasi menurun, maka IL-2 sebagai salah satu sitokin yang disekresi juga menurun kadarnya.

Sementara itu pada kelompok mencit yang hanya diberikan bisa Naja sputatrix memiliki kadar IL-2 yang paling tinggi. Hal ini mungkin karena bisa Naja sputatrix yang diberikan dengan sonde lambung dikenali sebagai antigen yang kemudian mengaktivasi limfosit T sehingga mensekresikan IL-2 ke dalam darah. Hasil ini melengkapi penelitian sebelumnya yang menyatakan adanya peningkatan kadar sitokin pada mencit dan manusia yang digigit oleh Bothrops asper dan Bothrops jararaca (Barraviera, Lomonte, Tarkowski, Hanson, \& Meira, 1955; Lomonte et al., 1993) dan dalam serum mencit yang diberi injeksi bisa Bothrops atrox (Barros, Friedlanskaia, Petricevich, \& Kipnis , 1998). Peningkatan kadar sitokin serta nitrit oksida juga ditemukan pada mencit yang diberi injeksi bisa Bothrops asper dan Bothrops jararaca (Petricevich et al., 2000). Kedua bisa ular tersebut memacu peningkatan yang signifikan pada Tumor Necrosis Factor (TNF), IL-1, IL-6 serta IL10 dalam serum darah mencit yang diinjeksi.

Pada kelompok mencit yang diinduksi dengan $\mathrm{B}(\mathrm{a}) \mathrm{P}$ dan dilanjutkan dengan pemberian bisa Naja sputatrix, kadar IL-2 nya hanya sedikit di atas kelompok mencit yang diinduksi B(a)P. Telah disebutkan bahwa induksi B(a)P mungkin menurunkan sistem imun seluler yang mengakibatkan penurunan produksi IL-2. Pemberian bisa Naja sputatrix tidak meningkatkan secara signifikan produksi IL-2 yang tersupresi akibat induksi B(a)P. Hal ini mungkin terjadi karena supresi terhadap sistem imun yang sedemikian kuat sehingga tidak lagi mampu mensekresi IL-2. Ada kemungkinan sistem imun mencit yang melemah karena induksi kanker dengan B(a)P semakin melemah akibat pemberian bisa Naja sputatrix yang dianggap sebagai antigen.

Perbedaan yang tidak signifikan antara kadar IL-2 tiap kelompok perlakuan mungkin juga disebabkan karena pembentukan kanker yang diinduksi dengan B(a)P belum sempurna. Induksi yang belum sempurna ini mungkin belum cukup memicu respon imun spesifik oleh limfosit T untuk menghasilkan IL-2.

\section{KESIMPULAN DAN SARAN}

Hasil penelitian ini menunjukkan ada perbedaan rerata kadar IL-2 dalam serum darah di antara Kelompok mencit kontrol; diberi bisa Naja sputatrix; B(a)P, serta kelompok menerima B(a)P dan bisa Naja sputatrix, namun perbedaan tersebut secara statistik tidak bermakna.

Berdasarkan hasil penelitian disarankan tiga hal berikut ini.

1. Perlu diperhatikan lama induksi dengan $B(a) P$ untuk mendapatkan respon imun yang spesifik dalam percobaan.

2. Perlu dilakukan penelitian lebih lanjut untuk mengetahui mekanisme efek antitumor bisa ular kobra. 
3. Perlu dilakukan penelitian lebih lanjut untuk mengetahui hubungan antara pemberian bisa ular kobra dengan kadar IL-2 sebagai alternatif dalam pencegahan kanker.

\section{REFERENSI}

Anonim. (1998). Definition cobra venom. Online Medical Dictionary. Newcastle: University of Newcastle.

Bal,FA., Drexhage, HA., Von Blomberg, M., Weltevreden, EF., Veldhuizen, RW., Mullink, R., et al (1984). Mononuclear phagocyte function in head and neck cancer. Chemotactic responsiveness of blood monocytes in correlation between histologic grade of the tumor and infiltration of these cells into the tumor area. Cancer, Sep 15, 54(6), 1010-5.

Baratawidjaya, KG. (1988). Imunologi dasar. Jakarta: FKUI.

Barraviera, B., Lomonte, B., Tarkowski, A., Hanson, LA., \& Meira, DA. (1995). Acute-phase reactions including cytokines in patients bitten by Bothrops and Crotalus snakes in Brazil. J. Venom. Anim. Toxins, 1: 11-22.

Barros, SF., Friedlanskaia, I., Petricevich, VL., \& Kipnis,TL. (1998). Local inflammationlethality and cytokine release in mice injected with Bothrops atrox Venom. Med. Inflm, 7, 39-46.

Bragança, BM; Patel, NT., \& Bradinath, PG. (1967). Isolation and properties of a cobra venom factor selectively cytotoxic to yoshida sarcoma cells. Biochim. Biophys. Acta, 136(3); 508-520.

Calmette,A., Saenz, A., \& Costil, L. (1933). Effects du venin de cobra sur les greffes cancereuses et sur le cancer spontane (adeno-carcinome) de la souris. C. R. Acad. Sci, 197-205.

Feofanov,AV., Sharonov. GV., Astapova, MV., Rodionov, DI., Utkin, YN., \& Arseniev, AS. (2005). Cancer cell injury by cytotoxins from cobra venom is mediated through lysosomal damage. Biochem. J, Agustus 15. 390(Pt1), 1-8.

Ganesha, A. (2001). The depletion mechanism of complement after cobra venom induction. Nature. IV(26). New York.

Heussen, GAH., Post. JG., \& Alink, GM. (1990). Genotoxicity of B(a)P2-nitrofluorene and airborne particulare in the DNA-repair host mediated assay. Mutation Res, 241(1), 83-89.

Kapitulnik, J., Wislocki, PG., Levin, W., Yagi, H., Jerina, DM., \& Coney, AH. (1978). Tumoreginicity studies with Diol-Epoxides of Benzo(a)pyrene which indicate that $( \pm)$-trans-7ß $8 \alpha$-Dihydroxy$9 \alpha 10 \alpha$-epoxy-7 8910 -tetrahydrobenzo(a)pyrene is an ultimate carcinogen in newborn mice. Cancer Re. 38, 354.

Lomonte, B., Tarkowski, A., \& Hanson, LA. (1993). Host response to bothrops asper snake venom: Analysis of edema formation inflammatory cells and cytokine release in mouse model. Inflammation. 17(2), 93-105.

Mathé, G. (1976). Recent result in cancer research: Cancer active immuno therapy immuno prophylaxis and immuno restoration. An introduction. Berlin-Heidelberg-New York: SpringerVerlag.

Pal, SK., Gomes, A., Dasgupta, SC., \& Gomes, A. (2002). Snake venom as therapeutic agents: From toxin to drug development. Indian J Exp Biol. Dec. 40(12), 1353-8.

Roitt, I., Brostoff, J., \& Male, D. (1996). Immunology (4thed). Barcelona: Times Mirror International Publishers Limited.

Roitt, M. (1991). Essential immunology. Oxford: Blackwell Science Publication.

Shaikh, DM, Jamali, AG., Ansari, AF., \& Seehar, GM. (1986). Safe and effective dosage for normal (rabbit) and human hepatic cancer cell. Pak J Zoo, 18, 187-193. 
Jurnal Matematika, Sains, dan Teknologi, Volume 10, Nomor 2, September 2009, 75-80

Soedigdo, P. (1975). Mekanisme karsinogenesis. Makalah disampaikan pada Kongres ke-4 Ikatan Ahli Patologi Indonesia. Bandung.

Wagener, DJ Th., Van de Velde, CHJ., \& Bosnan, FT. (1999). Onkologi Edisi V (Revisi). Alih bahasa Arjono. Yogyakarta: Panitia Kanker RSUP Dr. Sardjito. 